\title{
TECHNOLOGICAL INNOVATIONS FOR TREATMENT OF CASINGS
}

Vera V. Eveleva*, Tatyana M. Cherpalova, Elena A. Shipovskaya

All-Russia Research Institute for Food Additives -

Branch of V.M. Gorbatov Federal Research Center for Food Systems of RAS, St. Petersburg, Russia

Key words: casings, microbial contamination, treatment, technological aids, antimicrobial efficiency

\begin{abstract}
The article presents the results of substantiation of composition of technological aids for treatment of casings, which provides an increase in microbiological safety of the finished product. The study objects were samples of casings with signs of microbial spoilage, provided by the manufacturer, and prototypes of technological aids for treatment of casings obtained in VNIIPD. Parameters studied: microbial contamination of casings; titratable acidity, active acidity, density of test samples of the technological aids, surface tension and efficiency of aqueous solutions of the samples. Microbial contamination was determined using methods generally accepted in veterinary and sanitary examination; titratable acidity - titrimetric method; active acidity $(\mathrm{pH})$ - potentiometric method; density - densimetric method; surface tension - ring method (du Noüy method). It was found that the surface microbial contamination of defective intestinal membranes includes the following microorganisms: Bacillus spp., Enterococcus spp. and Micrococcus spp. Among the microorganisms the most resistant to various types of treatment are Bacillus spp. microorganisms. It was established, that the samples of the tested synthesized prototypes of technological aids with most effective antimicrobial action were samples based on lactate-, acetate- and propionate-containing additives, including polyhexamethylene guanidine hydrochloride and alkyldimethylbenzylammonium chloride. It was shown, that test prototypes 9, 19, and 28, which include polyhexamethyleneguanidine hydrochloride, alkyldimethylbenzylammonium chloride and polyvinylpyrrolidone, have rather high antagonistic activity against test cultures of L. monocitogenes, E. coli, St. aureus, Sal. typhimurium with the folowing concentration - $\left(600 \times 10^{6} \mathrm{CFU} / \mathrm{ml}\right)$. Minimum effective concentrations of solutions of technological aids for treatment of casings vary from $0,6 \%$ up to $2,5 \%$. It was established that minimum effective concentration of solutions of technological aids for treatment of casings corresponds to concentration of the solution with maximum adsorption of the resulting complexes on the surface of the liquid-air phase boundary. Treatment of defective casings with aqueous solutions of the agents with concentrations of $2.5 \%$ for 30 minutes provides suppression of growth of all detected spoilage microorganisms, including Bacillus spp.
\end{abstract}

\section{Introduction}

From the very beginning of development of industrial production of sausages, the casings have been used in production of boiled, smoked or liver sausages, wieners, thick wieners and other products. One of the main advantages of natural casings is the ability to shrink at heat treatment of sausages. At the same time, the casings are perishable products that can not be subjected to thermal preservation.

The task of preservation of high quality of raw casings and natural sausage casings for a sufficiently long storage time is one of most technologically important. In the world and domestic practice casings are preserved, mainly, with salting, which leads to a change in the species of their microbial contamination. Microflora of salted casings mainly consists of salt-resistant microorganisms. When stored in uncontrolled temperature conditions, salty casings are affected by red spots and rot [1,2]. In addition it can also be affected with verocytotoxigenic Escherichia coli and antibiotic-resistant microorganisms Salmonella and Enterococciis, Campylobacter spp is possible., Listeria monocytogenes and Enterobacter sakazakit [3]. In this regard, studies aimed at creating effective technological aids for treatment of casings are relevant.
Commonly used preservatives for improvement of storage capacity of casings are curing mixtures, including acetic, tartaric, lactic and citric acids, their salts and phosphates, sodium salt of dehydracetic acid or sodium salt of dehydracetic acid with sodium benzoate or sodium sorbate, or with sodium propionate $[4,5]$. In order to increase softness and elasticity of the casings, treatment of raw casings is carried out using a mixture of pepsin with lactic acid [6]. In order to increase antimicrobial and antioxidant protection of the casings we have offered a composition of a curing mixture containing sodium salt of dehydracetic acid or a mixture of a sodium salt of dehydracetic acid with polyvinylpyrrolidone, a salt of edible acid and dihydroquercetin [7]. We have established an efficiency of a preparation, which contains sodium salt of dehydracetic acid against all the microorganisms most frequently encountered in the meat processing industry (gram-negative bacilli of the following geni: Escherichia, Proteus, Pseudomonas, Salmonella, actinomycetes, fungi of Pénicillium, Aspergillus, Mucor geni, and Torulopsis yeasts) [8]. Antimicrobial compositions, including food acids, salts of edible acids and compounds of polyguanidine, also suppress vital activity of microorganisms due to formation of monomolecular protective polymer film on the treated surface $[9,10,11]$. 
Currently, a number of compositions are known, including alkyldimethylbenzylammonium chloride, which belongs to the 3rd class of danger, as an active antimicrobial substance. In order to reduce toxicity of Quaternary ammonium bases, the compositions with polymers are created [12].

Based on the results of patent information search for materials about preservation and microbiological safety of casings, it was stated that solution to these problems can be achieved using antimicrobial agents containing edible organic acids, their salts, polymeric compounds and salts of Quaternary ammonium bases.

Purpose of the work: conducting researches aimed at development of prototypes of technological aids for treatment of casings and selection of the most effective of them for application in production of natural sausage casings.

\section{Materials and methods}

The study objects were:

- samples of casings (pork and beef rounds) with signs of microbial spoilage (with defects) and without them, provided by the manufacturer of natural sausage casings takenfrom four batches;

- test prototypes of technological aids for treatment of the casings, obtained in the course of experimental studies, 29 pieces, liquid in appearance, with different composition and physical-chemical parameters, stated in the Table 1.

Experimental tests were carried out using laboratory equipment of VNIIPD and methods commonly used in practice, in accordance with current regulatory and technical documentation.

Analyzed parameters: sensitivity of the microorganisms to antibacterial drugs, titratable acidity, active acidity and density of test samples of technological aids and surface tension of aqueous solutions of samples of the agents.

The following parameters were evaluated: sensitivity of microorganisms to antibacterial medicines using standard methods (disk diffusion and serial dilution) according to procedural guidelines MUK 4.2.1890-04; titratable acidity - acid-base titration method; active acidity $(\mathrm{pH})-$ potentiometric method using $\mathrm{pH}$-meter $\mathrm{pH}-150 \mathrm{MI}$; density - densimetric method using General purpose hydrometers $\mathrm{AON}-1$ with different ranges of measurement; surface tension - ring method using du Noüy tensiometer, made of platinum ring, vessel with test liquid, table and torsion scale with measurement range from 0 up to 360 c.u. and division value 1 c.u.

Triple studies were carried out, the results were processed using primary statistical analysis method.

\section{Results}

In the researches aimed at development of technological aids for the purpose of treatment of casings we have used ingredients permitted for use in food products «according to standard operating procedures» in accordance with the «Requirements to safety of food additives, flavorings and technological aids» TR TS 029/2012.

It is considered established that the effect of antimicrobial agents on pathogens of microbial damage of the casings is determined by their effect on protein synthesis, enzyme activity, cell membrane and DNA of microorganisms. The main factor of antimicrobial effect of the agents is violation of integrity of the cell membrane of microorganisms. Achievement of the required technological effect is provided by high solubility of antimicrobial agents in water and their high diffusion capacity.

Table 1 shows the results of determination of physical and chemical parameters of experimental samples of the compositions.

Table 1. Physical and chemical parameters of experimental samples of the agents

\begin{tabular}{|c|c|c|c|c|}
\hline Sample No. & Main prescription components of the samples & Active acidity, $\mathrm{pH}$ unit & Titratable acidity, degrees & Density, $\mathrm{g} / \mathrm{cm}^{3}$ \\
\hline 1 & $\begin{array}{l}\text { Polyhexamethylene guanidine hydrochloride, } \\
20 \% \text { solution }\end{array}$ & $9.9 \pm 0.1$ & $\mathbf{0}$ & $1.035 \pm 0.002$ \\
\hline 2 & $\begin{array}{l}\text { Lactic acid } \\
\text { Sodium hydroxide } \\
\text { Polyhexamethylene guanidine hydrochloride } \\
\text { Acetic acid } \\
\text { Propionic acid } \\
\text { Formic acid } \\
\text { Sulfamic acid } \\
\text { Oxalic acid } \\
\text { Ascorbic acid }\end{array}$ & $3.0 \pm 0.1$ & $87 \pm 1$ & $1.296 \pm 0.002$ \\
\hline 3 & $\begin{array}{l}\text { Lactic acid } \\
\text { Polyhexamethylene guanidine hydrochloride } \\
\text { Acetic acid } \\
\text { Propionic acid } \\
\text { Formic acid } \\
\text { Sulfamic acid } \\
\text { Oxalic acid } \\
\text { Ascorbic acid }\end{array}$ & $0.9 \pm 0.1$ & $130 \pm 1$ & $1.057 \pm 0.002$ \\
\hline
\end{tabular}




\begin{tabular}{|c|c|c|c|c|}
\hline Sample No. & Main prescription components of the samples & Active acidity, $\mathrm{pH}$ unit & Titratable acidity, degrees & Density, $\mathrm{g} / \mathrm{cm}^{3}$ \\
\hline 4 & $\begin{array}{l}\text { Sodium acetate } \\
\text { Sodium citrate } \\
\text { Sodium metabisulfite } \\
\text { Sulfamic acid } \\
\text { Oxalic acid } \\
\text { Ascorbic acid }\end{array}$ & $\begin{array}{c}\mathrm{pH} \text { of } 1 \% \text { solution } 5.9 \\
\pm 0.1\end{array}$ & $195 \pm 1$ & Solid form \\
\hline 5 & $\begin{array}{l}\text { Sodium lactate } \\
\text { Sodium acetate } \\
\text { Acetic acid } \\
\text { Propionic acid }\end{array}$ & $5.9 \pm 0.1$ & $45 \pm 1$ & $1.306 \pm 0.002$ \\
\hline 6 & $\begin{array}{l}\text { Polyhexamethylene guanidine hydrochloride } \\
\text { Alkyldimethylbenzylammonium chloride }\end{array}$ & $9.9 \pm 0.1$ & $\mathbf{0}$ & $1.034 \pm 0.002$ \\
\hline 7 & $\begin{array}{l}\text { Lactic acid } \\
\text { Acetic acid } \\
\text { Propionic acid } \\
\text { Formic acid } \\
\text { Sulfamic acid } \\
\text { Oxalic acid } \\
\text { Ascorbic acid } \\
\text { Polyhexamethylene guanidine hydrochloride } \\
\text { Alkyldimethylbenzylammonium chloride }\end{array}$ & $0.6 \pm 0.1$ & $250 \pm 1$ & $1.063 \pm 0.002$ \\
\hline 8 & $\begin{array}{l}\text { Glycerol } \\
\text { Polyhexamethylene guanidine hydrochloride } \\
\text { Alkyldimethylbenzylammonium chloride }\end{array}$ & $9.7 \pm 0.1$ & - & $1.055 \pm 0.002$ \\
\hline 9 & $\begin{array}{l}\text { Sodium lactate } \\
\text { Lactic acid } \\
\text { Acetic acid } \\
\text { Propionic acid } \\
\text { Polyhexamethylene guanidine hydrochloride } \\
\text { Alkyldimethylbenzylammonium chloride }\end{array}$ & $5.0 \pm 0.1$ & $151 \pm 1$ & $1.278 \pm 0.002$ \\
\hline 10 & \multirow{5}{*}{$\begin{array}{l}\text { Sodium lactate } \\
\text { Lactic acid } \\
\text { Acetic acid } \\
\text { Propionic acid }\end{array}$} & $4.1 \pm 0.1$ & $322 \pm 1$ & $1.260 \pm 0.002$ \\
\hline 11 & & $4.5 \pm 0.1$ & $251 \pm 1$ & $1.275 \pm 0.002$ \\
\hline 12 & & $5.0 \pm 0.1$ & $146 \pm 1$ & $1.287 \pm 0.002$ \\
\hline 13 & & $5.5 \pm 0.1$ & $71 \pm 1$ & $1.297 \pm 0.002$ \\
\hline 14 & & $5.9 \pm 0.1$ & $34 \pm 1$ & $1.301 \pm 0.002$ \\
\hline 15 & \multirow{9}{*}{$\begin{array}{l}\text { Sodium lactate } \\
\text { Lactic acid } \\
\text { Acetic acid } \\
\text { Propionic acid } \\
\text { Polyhexamethylene guanidine hydrochloride }\end{array}$} & $4.1 \pm 0.1$ & $305 \pm 1$ & $1.257 \pm 0.002$ \\
\hline 16 & & $4.3 \pm 0.1$ & $315 \pm 1$ & $1.266 \pm 0.002$ \\
\hline 17 & & $4.5 \pm 0.1$ & $248 \pm 1$ & $1.272 \pm 0.002$ \\
\hline 18 & & $4.5 \pm 0.1$ & $250 \pm 1$ & $1.274 \pm 0.002$ \\
\hline 19 & & $5.0 \pm 0.1$ & $157 \pm 1$ & $1.288 \pm 0.002$ \\
\hline 21 & & $4,4 \pm 0.1$ & $206 \pm 1$ & $1.231 \pm 0.002$ \\
\hline 22 & & $4.8 \pm 0.1$ & $121 \pm 1$ & $1.240 \pm 0.002$ \\
\hline 23 & & $5.3 \pm 0.1$ & $58 \pm 1$ & $1.250 \pm 0.002$ \\
\hline 24 & & $5.7 \pm 0.1$ & $28 \pm 1$ & $1.255 \pm 0.002$ \\
\hline \multirow[t]{2}{*}{25} & \multirow{3}{*}{$\begin{array}{l}\text { Lactic acid } \\
\text { Acetic acid } \\
\text { Propionic acid } \\
\text { Alkyldimethylbenzylammonium chloride }\end{array}$} & $4.1 \pm 0.1$ & $321 \pm 1$ & $1.259 \pm 0.002$ \\
\hline & & $4.5 \pm 0.1$ & $250 \pm 1$ & $1.272 \pm 0.002$ \\
\hline 26 & & $5.0 \pm 0,1$ & $144 \pm 1$ & $1.286 \pm 0.002$ \\
\hline 27 & \multirow{3}{*}{$\begin{array}{l}\text { Sodium lactate } \\
\text { Lactic acid } \\
\text { Acetic acid } \\
\text { Propionic acid } \\
\text { Polyvinylpyrrolidone } \\
\text { Alkyldimethylbenzylammonium chloride } \\
\text { Sodium lactate } \\
\text { Lactic acid } \\
\text { Acetic acid } \\
\text { Propionic acid } \\
\text { Polyvinylpyrrolidone } \\
\text { Alkyl dimethyl benzyl ammonium chloride }\end{array}$} & $4.0 \pm 0.1$ & $263 \pm 1$ & $1.229 \pm 0.002$ \\
\hline 28 & & $4.4 \pm 0.1$ & $205 \pm 1$ & $1, .222 \pm 0.0002$ \\
\hline 29 & & $4.5 \pm 0,1$ & $227 \pm 1$ & $1.250 \pm 0.002$ \\
\hline
\end{tabular}


Table 2. Evaluation of antimicrobial activity of experimental samples of technological aids in relation to pathogens of microbial spoilage of casings

\begin{tabular}{|c|c|c|c|c|c|c|}
\hline \multirow{2}{*}{$\begin{array}{c}\text { Sample } \\
\text { No. }\end{array}$} & \multicolumn{2}{|c|}{ Acidity } & \multirow{2}{*}{$\begin{array}{c}\text { Concentration } \\
\text { of aqueous solution } \\
\text { of the agent, } \%\end{array}$} & \multicolumn{3}{|c|}{ Type of causative agent of microbial spoilage of the raw casings } \\
\hline & titratable, degrees & active, $\mathrm{pH}$ units & & Bacillus spp. & Enterococcus spp. & Micrococcus spp. \\
\hline \multirow{2}{*}{1} & \multirow{2}{*}{$\mathbf{0}$} & \multirow{2}{*}{9.9} & 5 & + & - & - \\
\hline & & & 2.5 & + & + & + \\
\hline \multirow{2}{*}{5} & \multirow{2}{*}{200} & \multirow{2}{*}{5.8} & 5 & + & + & + \\
\hline & & & 2.5 & + & + & + \\
\hline \multirow{2}{*}{2} & \multirow{2}{*}{170} & \multirow{2}{*}{4.9} & 5 & + & - & - \\
\hline & & & 2.5 & + & + & + \\
\hline \multirow{3}{*}{3} & \multirow{3}{*}{90} & \multirow{3}{*}{3.1} & 10 & + & + & + \\
\hline & & & 5 & + & + & + \\
\hline & & & 2.5 & + & + & + \\
\hline \multirow{3}{*}{4} & \multirow{3}{*}{130} & \multirow{3}{*}{0.9} & 10 & + & - & - \\
\hline & & & 5 & + & - & - \\
\hline & & & 2.5 & + & + & + \\
\hline
\end{tabular}

Table 3. Evaluation of antimicrobial activity of experimental samples of technological aids in relation to pathogens of microbial spoilage of casings

\begin{tabular}{|c|c|c|c|c|}
\hline $\begin{array}{c}\text { Sample } \\
\text { No. }\end{array}$ & $\begin{array}{c}\text { Concentration of aqueous } \\
\text { solution of the agent, } \%\end{array}$ & Bacillus spp. & Type of microorganisms isolated from defective casings & Micrococcus spp. \\
\hline \multirow{2}{*}{} & 5 & - & - & - \\
\hline 28 & 2.5 & - & - & - \\
\hline
\end{tabular}

Determination of total microbial contamination of washes of the casings with signs of microbial spoilage showed that washes have significant microbial contamination. Microflora of the surface of the casings consists of cultures of Bacillus spp., Enterococcus spp. and Micrococcus spp. geni.

Table 2 shows the results reflecting the effect of the composition, titratable and active acidity of the technological aids prototypes and concentration of their aqueous solutions on effectiveness of antimicrobial treatment of the casings.

For the purpose of increase in antagonistic activity of technological aids, especially in relation to cultures of the genus

Bacillus. Bacillus spp., experimental samples including polyhexamethylene guanidine hydrochloride and alkyldimethylbenzylammonium chloride were synthesized. Physical and chemical parameters of the listed prototypes with introduced antimicrobial substances are shown in Table 1.

Microbiological studies have shown that the tested samples inhibit the growth of enterococcal cultures Enterococcus spp. and Micrococcus spp. with a significant slowdown in the growth of cultures of the Bacillus genus - Bacillus spp. At the same time, it was noted that some samples worsened the consumer properties of casings, making them «dry».

For the purpose of elimination of «dryness» of the treated surface we have prepared prototypes which physical and chemical parameters are significantly different from the previous prototypes, including polyvinylpyrrolidone (Table 1).
Antimicrobial activity of the tested samples in relation to Enterococcus spp., Micrococcus spp. and Bacillus spp. cultures was studied, they showed their effectiveness, which is reflected in the table 3 for the samples 9 and 28 .

Positive results of evaluation of antimicrobial effect of experimental samples 9 and 28, including polyhexamethylene guanidine hydrochloride, alkyldimethylbenzylammonium chloride and polyvinylpyrrolidone, on pathogens of microbial spoilage of the casings are confirmed by the changes in the surface activity of these samples in comparison with their basis (sample 12), shown in Figure 1.

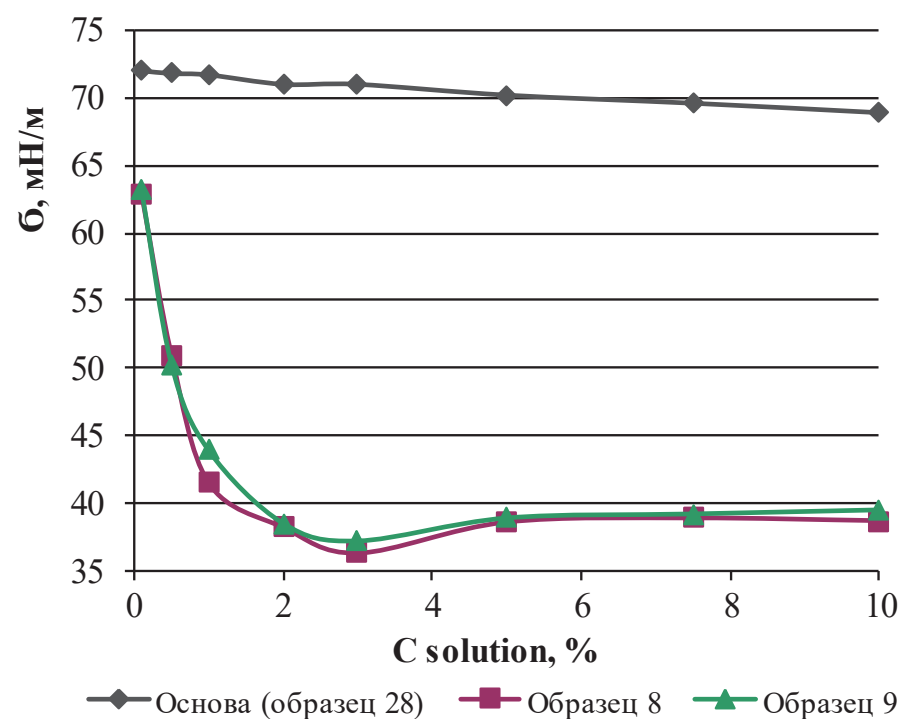

Figure 1. Change of surface tension $(\sigma, \mathrm{mN} / \mathrm{m})$ of aqueous solutions of technilogical aid at the liquid-air phase boundary depends on its concentration (C solution, \%) 


\section{Discussion}

Conducted studies of microbial contamination of fresh raw casings have found significant contamination (from several thousand up to tens of thousands and more microbial cells per $1 \mathrm{~g}$ ). The data obtained are consistent with the known data that the primary treatment of raw casings using traditional technology provides only partial removal (from 65 up to $70 \%$ ) of the original microflora.

As a result of the multi-faceted bacteriological studies we have identified microorganisms which most often occupy the surface of the defective casings: Bacillus spp., Enterococcus spp. and Micrococcus spp. It was found that the microorganisms most resistant to various types of treatment are Bacillus spp.

At preparation of prototypes of technological aids for treatment of the casings we used ingredients with antimicrobial action. The ingredients in the samples tested include sodium metabisulfite E223, E236 formic acid, acetic acid E260, sodium acetate E262, lactic acid E270, propionic acid E280, ascorbic acid E300, citric acid E330, sodium citrate food 3-substituted 2-water E331(iii), glycerin E422, sulfamic acid, oxalic acid, polyhexamethylene guanidine hydrochloride and alkyldimethylbenzylammonium chloride.

As a result of comparative studies, it was found that the tested prototypes with the most effective antimicrobial action were samples based on lactate, acetate and propionate-containing additives, including polyhexamethylene guanidine hydrochloride, alkyldimethylbenzylammonium chloride and polyvinylpyrrolidone. Treatment of defective casings with aqueous solutions of experimental samples of the agents with concentrations of 2,5\% to 5,0 \% for 30 minutes provides suppression of growth of all detected spoilage microorganisms, including Bacillus spp.
In order to identify a possible mechanism of action of the tested prototypes of the agents for treatment of casings, an assessment of their surface activity was carried out. We have found synergetic reduction of the surface tension of aqueous solutions of the prototypes of the agents in comparison with the characteristics of the surface tension of their base. The data obtained are indicative of formation in the process of synthesis of experimental samples of complexes of cationic high-molecular and surfactants with anions of lactic, acetic and propionic acids, contributing to increase of their antimicrobial efficiency.

As a result of theoretical and experimental studies we have substantiated a list of technological aids for treatment of casings, which provides a significant increase in microbiological safety of the finished products.

\section{Conclusion}

Significant microbial contamination of defective casings includes the following microorganisms: Bacillus spp., Enterococcus spp. and Micrococcus spp. Among these microorganisms the most resistant to various types of treatment of raw casings are Bacillus genus microorganisms Bacillus spp.

The samples of the tested synthesized prototypes of technological aids intended for treatment of casings with most effective antimicrobial action were samples based on lactate, acetate and propionate-containing additives, including polyhexamethylene guanidine hydrochloride, alkyldimethylbenzylammonium chloride and polyvinylpyrrolidone.

We have proposed a hypothetical conception of formation in the process of synthesis of complexes of cationic high-molecular substances and surfactants with anions of lactic, acetic and propionic acids, which provide an increase in antimicrobial efficiency of agents for treatment of the casings.

\section{REFERENCES}

1. Tatusov, Y.V., Krekhov, N.M., Sus, I.V. (2001). Use of preservatives for storage of natural sausage casings. Storage and processing of farm products, 10, 42-44. (in Russian)

2. Semenova, A.A., Kuznetsova, T.G., Dydykin, A.S., Nasonova, V.V., Mileenkova, E.V., Kulikovsky, A.V., Lazarev, A.A. (2017). Comparative study of quality of cooked smoked sausages in different types of sausage casings. Vsyo o myase, 2, 24-29

3. Sheveleva, S.A. (2006). The analysis risk of contamination microorganism food products. Voprosy Pitaniia, 75(5), 56-65. (in Russian)

4. Bakker, W.A.M., Houben, J.H., Koolmees, P.A., Bindrich, U., Sprehe L. (1999). Effects of initial mild curing, with additives, of hog and sheep sausage casings on their microbial quality and mechanical properties after storage at difference temperatures. Meat Science, 51(2), 163-174. DOI: 10.1016/s03091740(98)00118-1

5. Sidorova, E.V., Sus, I.V. (2011). Casing production. Science and practice. $M$, Editorial service. -228 p. ISBN: 978-59901348-5-0. (in Russian)
6. Sakata, R., Segowa, S., Marita, H. (1998). Histological and biochemical evaluation of connective tissue of natural hog and sheep casings. Fleischwirtschaft, 78(45), 371-372.

7. Snezhko, A.G., Kuznetsova, L.S., Borisova, Z.S., Ivanova, M.A. Sausage casing. Patent RF, no. 2151514, 2000. (in Russian)

8. Novikov, V.M., Snezhko, A.G., Borisova, Z.S., Rozantsev, E.G. (2007). Efficiency of use of antimicrobial preparations in production of semi-smoked and cooked and smoked sausages. Meat industry, 2, 61-64. (in Russian)

9. Gembitsky, P. A., Efimov K.M., Snezhko, A.G., Dityuk, A.I.Pat. Composition of protective coating for carcasses of slaughtered animals. Patent RF, no. 2268596, 2006. (in Russian)

10. Eveleva, V.V., Cherpalova, T.M. (2016). To the Question of Anti-Microbial Treatment of Natural Casings for Sausage Products. Food industry, 8, 40-42. (in Russian)

11. Eveleva, V.V., Cherpalova, T.M. (2017). Technological auxiliary agent for treatment of natural sausage casings. Food Processing: Techniques and Technology, 3(46), 29-35. DOI: 10.21179/20749414-2017-3-29-35. (in Russian)

12. Eveleva, V.V., Cherpalova, T.M. Composition for processing of natural sausage casings. Patent RF, no.2653600, 2018. (in Russian) 


\section{AUTHOR INFORMATION}

Vera V. Eveleva - candidate of technical sciences, docent, Chief Researcher, Laboratory of technology and processing of biosynthesis products, All-Russian Research Institute for Food Additives - Branch of V.M. Gorbatov Federal Research Center for Food Systems of RAS, 191014, St.-Petersburg, Liteyny prospekt, 55, Tel: +7-812-273-41-08, e-mail: v.eveleva@yandex.ru ${ }^{*}$ corresponding author

Tatyana M. Cherpalova - candidate of technical sciences, Researcher, Laboratory of technology and processing of biosynthesis products, All-Russian Research Institute for Food Additives - Branch of V.M. Gorbatov Federal Research Center for Food Systems of RAS, 191014, St.-Petersburg, Liteyny prospekt, 55, Tel: +7-812-272-56-26, e-mail: tcherpalova@yandex.ru

Elena A. Shipovskaya - research assistant, Laboratory of technology and processing of biosynthesis products, All-Russian Research Institute for Food Additives - Branch of V.M. Gorbatov Federal Research Center for Food Systems of RAS, 191014, St.-Petersburg, Liteyny prospekt, 55, Tel: +7-812-272-56-26, e-mail: alena.shipovskaja@yandex.ru

Authors are equally relevant to the writing of the manuscript, and equally responsible for plagiarism

The authors declare no conflict of interest

Received 15.04.2019 Accepted in revised 07.06.2019 Accepted for publication 10.06.2019 